Zusammenfassung. Luxationen und Luxationsfrakturen der Halswirbelsäule, ebenso Schleuderverletzungen ohne röntgenologisch faßbaren Befund, aber mit neurologischen Ausfällen, fordern eine vordringliche Versorgung. Bei einwandfreiem röntgenologischen Nachweis einer Luxation bzw. Luxationsfraktur ist eine sofortige Extension, Reposition und Operation angezeigt. Bei Schleudertraumen ohne röntgenologisch faßbare Zeichen im Nativbild, aber mit neurologischen Ausfällen (Paresen, Querschnittsyndrom) beispielsweise als Folge einer Bandscheibenruptur, ist ebenfalls eine unmittelbare Abklärung erforderlich. Dies gelingt am schnellsten mit der Disographie, die auch entscheidend für eine operative Indikation ist. Die modernen Operationsverfahren der ventralen Fusion haben gegenüber allen anderen Maßnahmen den großen Vorteil, daß keine weitere Ruhigstellung erforderlich ist, so daß bei Vorliegen von Kombinationstraumen die Versorgung anderer Verletzungen, wie z. B. Extremitätenfrakturen, zeitgerecht erfolgen kann.

\title{
15. Zur Versorgung der traumatischen Milz- und Zwerchfellrupturen bei kombinierten Verletzungen
}

\author{
R. Wenzee, R. Bähr*, B. Petrecic und F. Krause-Tübingen
}

\author{
Traumatic Spleen and Diaphragm Ruptures in Cases \\ of Multiple Injuries
}

Summary. The problem of multiple injuries involving the spleen and diaphragm lies in a timely diagnosis. This is of particular importance in cases where there is a brain injury with deep unconsciousness.

Measurement of the central venous pressure and recording blood pressure and pulse for a short time has been shown to be the best diagnostic measure for rupture of the spleen. In the case of ruptures of the diaphragm, any shadow in the thorax with accompanying dyspnoea or every corresponding trauma should make one suspect this injury.

In view of its effeet on the circulation and respiration, rupture of the diaphragm is an indication for immediate operation. An improvement in the results can only be expected if the diagnosis is prompt.

Zusammenfassung. Das Problem der Mehrfachverletzungen mit Milz- und Zwerchfellbeteiligung liegt in der rechtzeitigen Diagnose. Dies gilt besonders für die Fälle, in denen ein Schädel-Hirntrauma mit tiefer Bewußtlosigkeit vorliegt.

Als beste diagnostische Maßnahme hat sich bei den Milzrupturen die Messung des zentralen Venendruckes und die kurzzeitige Kontrolle von Blutdruck und Puls erwiesen. Bei Zwerchfellrupturen muß jede Verschattung des Thorax bei gleichzeitiger Dyspnoe bzw. jedes entsprechende Trauma den Verdacht auf diese Verletzung lenken.

Wegen der Auswirkungen auf Kreislauf und Atmung stellt die Zwerchfellruptur eine dringliche Operationsindikation dar. Eine Verbesserung der Ergebnisse ist nur von seiten der rechtzeitigen Diagnose zu erwarten. 